Nevada

Environmental

Restoration

Project

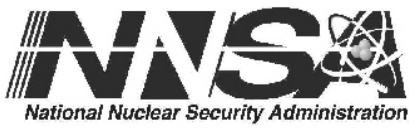

Corrective Action Plan for

Corrective Action Unit 543:

Liquid Disposal Units,

Nevada Test Site, Nevada

Controlled Copy No.:

Revision: 0

September 2006

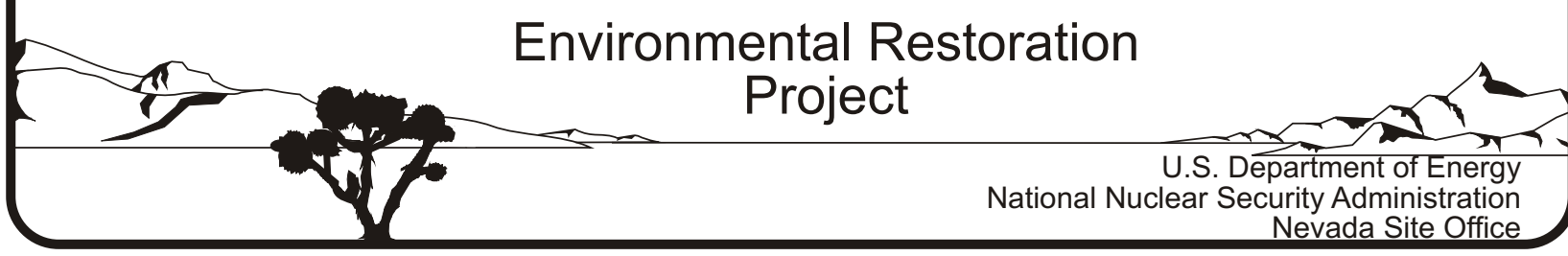




\section{DISCLAIMER}

Reference herein to any specific commercial product, process, or service by trade name, trademark, manufacturer, or otherwise, does not necessarily constitute or imply its endorsement, recommendation, or favoring by the United States Government or any agency thereof or its contractors or subcontractors.

This report has been reproduced directly from the best available copy.

Available for sale to the public from:

U.S. Department of Commerce

National Technical Information Service

5285 Port Royal Road

Springfield, VA 22161-0002

Telephone: (800) 553-6847

Fax: (703) 605-6900

E-mail: orders@ntis.gov

Online ordering: http://www.ntis.gov/ordering.htm

Available electronically at http://www.osti.gov/bridge.

Available for a processing fee to the U.S. Department of Energy and its contractors, in paper, from:

U.S. Department of Energy

Office of Scientific and Technical Information

P.O. Box 62

Oak Ridge, TN 37831-0062

Telephone: (865) 576-8401

Fax: (865) 576-5728

E-mail: reports@adonis.osti.gov 


\title{
CORRECTIVE ACTION PLAN FOR CORRECTIVE ACTION UNIT 543: LIQUID DISPOSAL UNITS, NEVADA TEST SITE, NEVADA
}

\author{
U.S. Department of Energy \\ National Nuclear Security Administration \\ Nevada Site Office \\ Las Vegas, Nevada
}

Controlled Copy No.

Revision: 0

September 2006 
THIS PAGE INTENTIONALLY LEFT BLANK 


\section{CORRECTIVE ACTION PLAN FOR CORRECTIVE ACTION UNIT 543: LIQUID DISPOSAL UNITS, NEVADA TEST SITE, NEVADA}
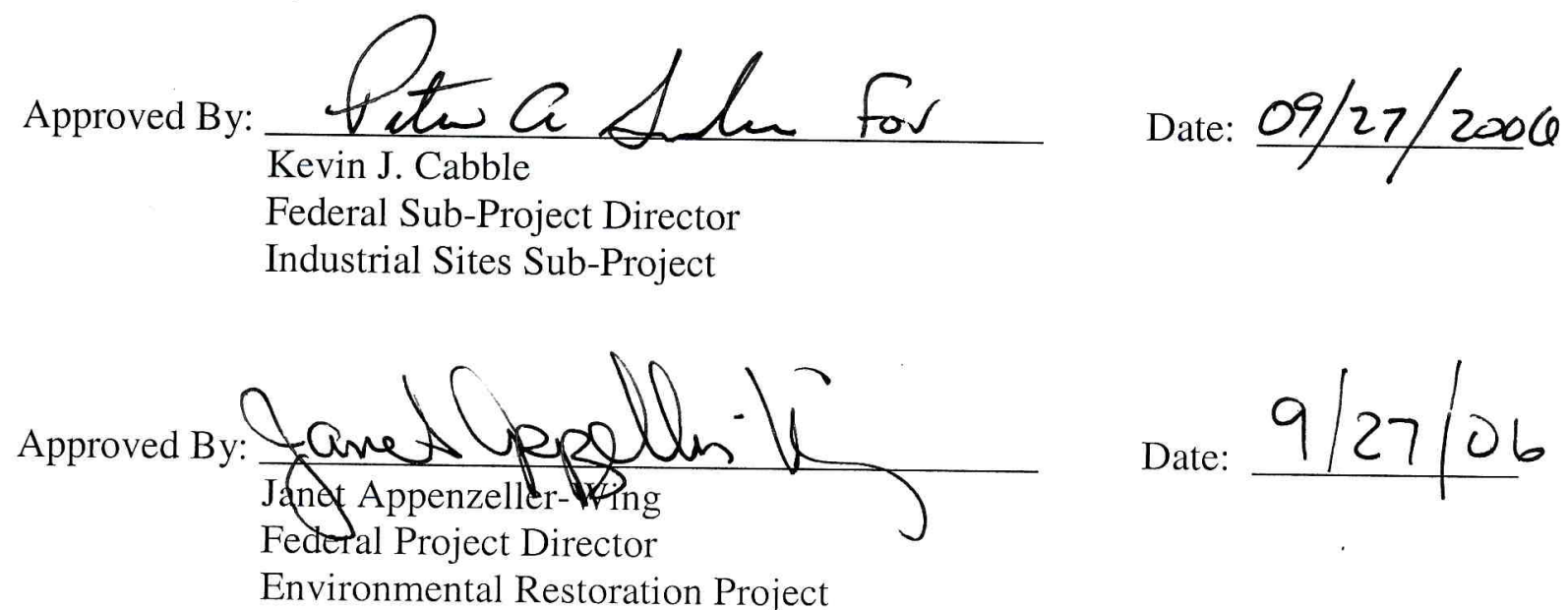
THIS PAGE INTENTIONALLY LEFT BLANK 


\section{TABLE OF CONTENTS}

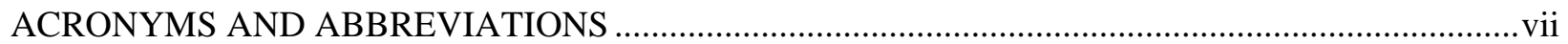

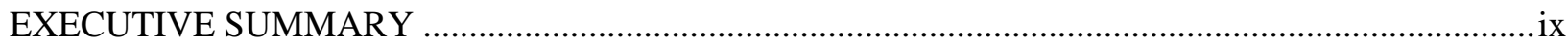

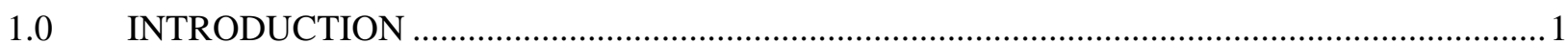

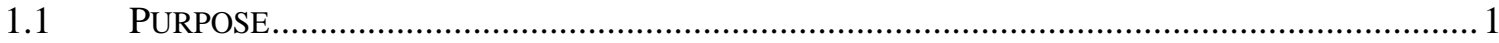

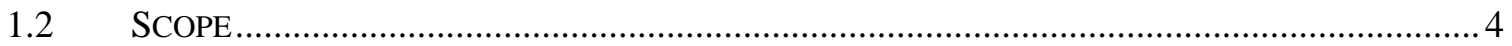

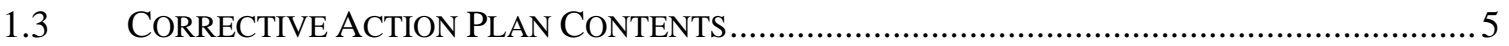

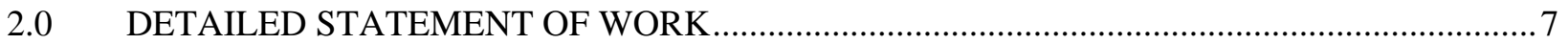

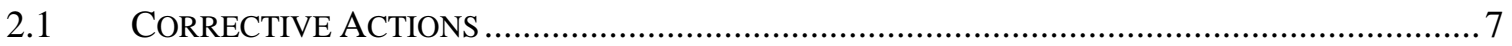

2.1.1 Alternative 1 - No Further Action .................................................................. 7

2.1.1.1 CAS 15-01-03, Aboveground Storage Tank ...................................... 7

2.1.1.2 CAS 15-04-01, Septic Tank......................................................... 7

2.1.1.3 CAS 15-05-01, Leachfield................................................................. 8

2.1.1.4 CAS 15-08-01, Liquid Manure Tank ............................................... 8

2.1.1.5 CAS 15-23-01, Underground Radioactive Material Area ..................... 8

2.1.2 Alternative 3 - Closure in Place with Administrative Controls.............................. 8

2.1.2.1 CAS 06-07-01, Decon Pad ................................................................ 9

2.1.2.2 CAS 15-23-03, Contaminated Sump, Piping........................................ 9

2.2 CONSTRUCTION QUALITY ASSURANCE / QUALITY CONTROL .........................................12

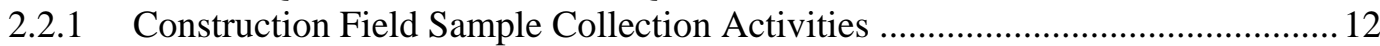

2.2.2 Construction Laboratory/Analytical Data Quality Indicators ............................... 12

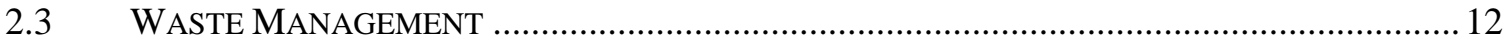

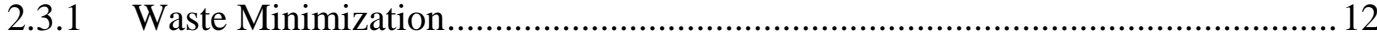

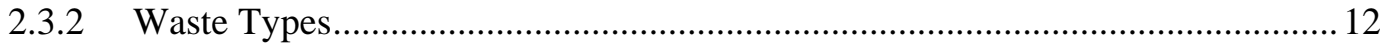

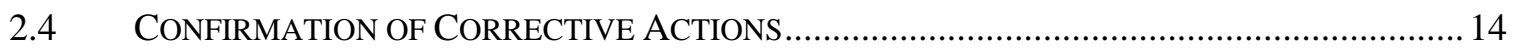

2.4.1 Sample Collection Methods ............................................................................... 14

2.4.2 Laboratory/Analytical Data Quality Objectives ............................................. 14

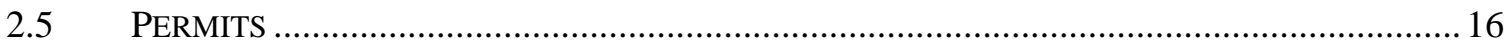

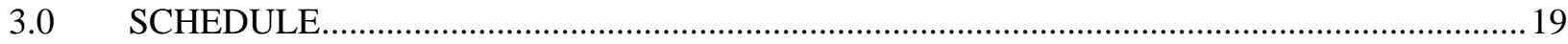

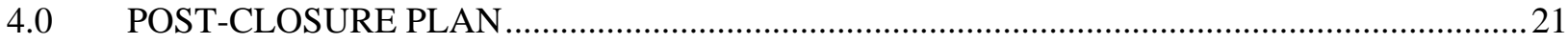

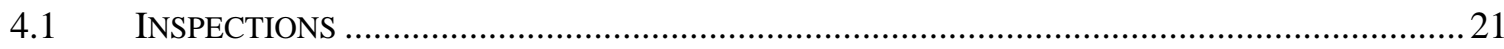

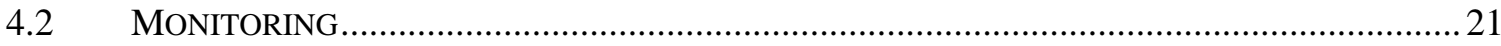

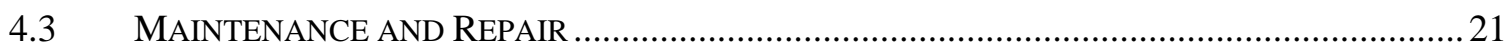

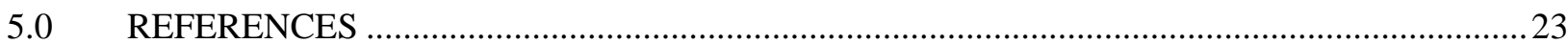

LIBRARY DISTRIBUTION LIST 


\section{LIST OF FIGURES}

FigURE 1. CAU 543 Site LoCATION MAP................................................................................... 2

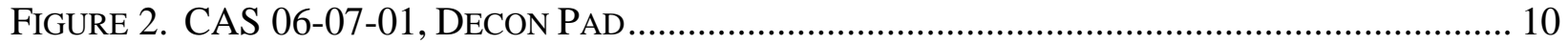

FIGURE 3. CASs 15-01-03, 15-04-01, 15-05-01, 15-08-01, 15-23-01, AND 15-23-03 LOCATED AT

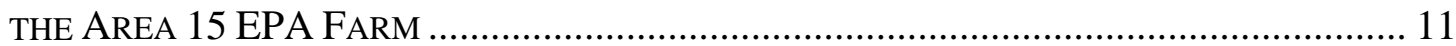

\section{APPENDICES}

APPENDIX A.1 Engineering Specifications and Drawings

APPENDIX A.2 Sampling and Analysis Plan

APPENDIX A.3 Project Organization 


\section{ACRONYMS AND ABBREVIATIONS}

AST

BMP

$\mathrm{BN}$

CADD

CAIP

CAP

CAS

CAU

COC

CR

DOE

$\mathrm{DOE} / \mathrm{NV}$

DQI

DQO

EPA

FFACO

$\mathrm{ft}$

gal

LLW

NDEP

NEPA

NNSA/NSO

NSTec

NTS

OI

OP

PCBs

PPE

PSP

QA
Aboveground Storage Tank

best management practice

Bechtel Nevada

Corrective Action Decision Document

Corrective Action Investigation Plan

Corrective Action Plan

Corrective Action Site(s)

Corrective Action Unit

contaminant(s) of concern

Closure Report

U.S. Department of Energy

U.S. Department of Energy, Nevada Operations Office

data quality indicator

data quality objective

U.S. Environmental Protection Agency

Federal Facility Agreement and Consent Order

foot (feet)

gallon(s)

low-level waste

Nevada Division of Environmental Protection

National Environmental Policy Act

U.S. Department of Energy, National Nuclear Security Administration Nevada Site Office

National Security Technologies, LLC

Nevada Test Site

Organization Instruction

Organization Procedure

polychlorinated biphenyls

personal protective equipment

perforated steel plate

quality assurance 


\section{ACRONYMS AND ABBREVIATIONS (continued)}

QC

REOP

RPD

RWP

TSD

UR

WGS

$\% \mathrm{R}$ quality control

Real Estate Operations Permit

relative percent difference

Radiological Work Permit

treatment, storage, and disposal

use restriction

Waste Generator Services

percent recovery 


\section{EXECUTIVE SUMMARY}

Corrective Action Unit (CAU) 543, Liquid Disposal Units, is listed in Appendix III of the Federal Facility Agreement and Consent Order of 1996. CAU 543 consists of seven Corrective Action Sites (CASs) located in Areas 6 and 15 of the Nevada Test Site, which is approximately 65 miles northwest of Las Vegas, Nevada. CAU 543 consists of the following seven CASs:

- CAS 06-07-01, Decon Pad

- CAS 15-01-03, Aboveground Storage Tank

- CAS 15-04-01, Septic Tank

- CAS 15-05-01, Leachfield

- CAS 15-08-01, Liquid Manure Tank

- CAS 15-23-01, Underground Radioactive Material Area

- CAS 15-23-03, Contaminated Sump, Piping

From January 24, 2005 through April 14, 2005, CAU 543 site characterization activities were conducted, and are reported in Appendix A of the CAU 543 Corrective Action Decision Document (CADD) (U.S. Department of Energy, National Nuclear Security Administration Nevada Site Office [NNSA/NSO], 2005). The recommended corrective action as stated in the approved CADD is No Further Action for five of the CAU 543 CASs, and Closure In Place for the remaining two CASs.

The site characterization results and the recommended closure activities according to the approved CADD (NNSA/NSO, 2005) for each CAS include the following:

- CAS 06-07-01, Decon Pad is located at the Area 6 Decontamination Facility, and no Contaminants of Concern (COCs) were reported above action levels during site characterization (NNSA/NSO, 2005). The CAS will be closed in place with administrative controls by posting appropriate use restriction (UR) warning signs around the perimeter of the Building 6-605 foundation and implementing a land UR, with best management practices (BMPs).

- CAS 15-01-03, Aboveground Storage Tank is located is located at the former U.S. Environmental Protection Agency (EPA) Farm in Area 15, and no COCs are present above action levels. The site will be closed by taking no further action (NNSA/NSO, 2005) with BMPs.

- CAS 15-04-01, Septic Tank, is located at the former EPA Farm in Area 15, and no COCs are present above action levels. The site will be closed by taking no further action (NNSA/NSO, 2005) with BMPs. 
- CAS 15-05-01, Leachfield, is located at the former EPA Farm in Area 15 and consists of a leachfield and distribution box southeast of the Building 06-15 foundation, and no COCs are present at this site above action levels. The site will be closed by taking no further action (NNSA/NSA, 2005) with BMPs.

- CAS 15-08-01, Liquid Manure Tank, is located at the former EPA Farm in Area 15, and no COCs are present above action levels. The site will be closed by taking no further action (NNSA/NSO, 2005) with BMPs.

- CAS 15-23-01, Underground Radioactive Material Area, is located at the former EPA Farm in Area 15, and no COCs are present above action levels. The site will be closed by taking no further action (NNSA/NSO, 2005) with BMPs.

- CAS 15-23-03, Underground Sump, Piping, is located at the former EPA Farm in Area 15 and consists of a sump and associated piping between the sump and the CAS 15-01-03 distribution box. Polychlorinated biphenyls and plutonium-238 concentrations above action levels are present in the soil at the sump floor, and the site will be closed in place with administrative controls by backfilling and compacting the sump with clean fill material, grading the sump area to prevent precipitation runon, and posting UR signage around the perimeter of the sump. 


\subsection{INTRODUCTION}

Corrective Action Unit (CAU) 543: Liquid Disposal Units is listed in Appendix III of the Federal Facility Agreement and Consent Order (FFACO) which was agreed to by the state of Nevada, the U.S. Department of Energy (DOE), and the U.S. Department of Defense (FFACO, 1996). CAU 543 sites are located in Areas 6 and 15 of the Nevada Test Site (NTS), which is approximately 65 miles northwest of Las Vegas, Nevada. CAU 543 consists of the following seven Corrective Action Sites (CASs) (Figure 1):

- CAS 06-07-01, Decon Pad

- CAS 15-01-03, Aboveground Storage Tank

- CAS 15-04-01, Septic Tank

- CAS 15-05-01, Leachfield

- CAS 15-08-01, Liquid Manure Tank

- CAS 15-23-01, Underground Radioactive Material Area

- CAS 15-23-03, Contaminated Sump, Piping

All Area 15 CASs are located at the former U.S. Environmental Protection Agency (EPA) Farm, which operated from 1963 to 1981 and was used to support animal experiments involving the uptake of radionuclides. Each of the Area 15 CASs, except CAS 15-23-01, are associated with the disposal of waste effluent from Building 15-06, which was the primary location of the various tests and experiments conducted onsite. Waste effluent disposal from Building 15-06 involved piping, sumps, outfalls, a septic tank with leachfield, underground storage tanks, and an aboveground storage tank (AST). CAS 15-23-01 was associated with decontamination activities of farm equipment potentially contaminated with radiological constituents, pesticides, and herbicides. While the building structures were removed before the investigation took place, all the original tanks, sumps, piping, and concrete building pads remain in place.

The Area 6 CAS is located at the Decontamination Facility in Area 6, a facility which operated from 1971 to 2001 and was used to decontaminate vehicles, equipment, clothing, and other materials that had become contaminated during nuclear testing activities. The CAS includes the effluent collection and distribution systems for Buildings 6-605, 6-606, and 6-607, which consists of septic tanks, sumps, piping, floor drains, drain trenches, cleanouts, and a concrete foundation.

Additional details of the site history are provided in the CAU 543 Corrective Action Investigation Plan (CAIP) (U.S. Department of Energy, National Nuclear Security Administration Nevada Site Office [NNSA/NSO], 2004), and the CAU 543 Corrective Action Decision Document (CADD) (NNSA/NSO, 2005).

\subsection{PURPOSE}

The purpose of this Corrective Action Plan (CAP) is to provide the detailed scope of work required to implement the recommended corrective actions as specified in the approved CADD (NNSA/NSO, 2005). 
Date: September 2006

Figure 1. CAU 543 Site Location MAP 
CAU 543 consists of seven CASs located in Areas 6 and 15 of the NTS. The sites were characterized in 2005 according to the approved CAIP (NNSA/NSO, 2004). The results of the site characterization are reported in Appendix A of the CAU 543 CADD (NNSA/NSO, 2005).

CAS 06-07-01, Decon Pad, is located at the Decontamination Facility in Area 6. The CAS consists of the effluent collection and distribution systems for Buildings 6-605, 6-606, and 6-607, which include two 1,000-gallon (gal) septic tanks, two ground-level sumps and associated piping, the concrete foundation of Building 6-605, floor drains, drain trenches, and cleanouts. Polychlorinated biphenyls (PCBs) are the only contaminants of concern (COCs) present above action levels in the soil around the Decontamination Facility foundation.

CAS 15-01-03, Aboveground Storage Tank, is located at the former EPA Farm in Area 15 and consists of a radiologically contaminated 25,000-gal tank located within a pit south of the former location of Building 15-06 as well as the associated piping between the tank and the Building 15-06 foundation, and the exterior holding pens. The tank, which was originally located at the Area 5 Contaminated Waste Dump, contains waste from the metabolism and slaughter rooms within Building 15-06 as well as waste from the holding pens. No COCs are present above action levels (NNSA/NSO, 2005).

CAS 15-04-01, Septic Tank, is located at the former EPA Farm in Area 15 and consists of a 1,000-gal septic tank, piping, and a cleanout southeast of Building 15-06. Four floor drains, four sinks, and one toilet discharged to the septic tank from the Small Animal Laboratory, Biology Laboratory, Utility Room, and restroom within Building 15-06. No COCs are present above action levels (NNSA/NSO, 2005).

CAS 15-05-01, Leachfield, is located at the former EPA Farm in Area 15 and consists of a leachfield and distribution box southeast of the Building 06-15 foundation. No COCs are present at this site above action levels (NNSA/NSA, 2005).

CAS 15-08-01, Liquid Manure Tank, is located at the former EPA Farm in Area 15 and consists of a liquid manure tank, associated piping, and a concrete pad and drain northwest of the Building 15-06 foundation, which were used for the disposal of excess milk from the dairy cows, and wastes from the autopsy laboratory, milking room, and metabolism room. No COCs are present above action levels (NNSA/NSO, 2005).

CAS 15-23-01, Underground Radioactive Material Area, is located at the former EPA Farm in Area 15 and consists of an area of soil surrounding and underlying a perforated steel plate (PSP) (e.g., grate) measuring approximately 19 by 22 feet (ft). No COCs are present above action levels (NNSA/NSO, 2005). 
CAS 15-23-03, Contaminated Sump, Piping, is located at the former EPA Farm in Area 15 and consists of a sump and associated piping between the sump and the CAS 15-01-03 distribution box. The sump was used primarily for the collection of liquid waste from the Building 15-06 laboratory. PCB and plutonium-238 concentrations above action levels are present in the soil at the sump floor, with the contamination confined laterally by the concrete side walls and vertically by a hard, underlying stratigraphic layer. The site will be closed in place with administrative controls by backfilling and compacting the sump with clean fill material, reestablishing appropriate signage around the perimeter of the sump, and establishing a site monitoring program.

\subsection{SCOPE}

The CADD identifies Closure in Place with Administrative Controls as the preferred corrective action for CASs 06-07-01 and 15-23-03 and No Further Action for the remaining CASs of CAU 543 (NNSA/NSO, 2005). Briefly, the scope of work to implement this corrective action includes the following.

CAS 06-07-01, Decon Pad, will be closed in place with administrative controls by posting appropriate use restriction (UR) warning signs around the perimeter of the Building 6-605 foundation and implementing a land UR. As a best management practice (BMP), the contents of the septic tanks, Sumps 1 and 2, and diversion boxes as well as the septic tanks, sumps, and associated piping will be removed, solidified if necessary, and/or excavated and disposed of in an appropriate facility. Additionally, all floor drains and trenches will be filled with concrete and all open holes, diversion boxes, and cleanouts will be grouted to grade. Any remaining debris, containers, drums, and associated waste within the storage yard will be sampled, if necessary, and disposed of at an appropriate facility.

CAS 15-01-03, Aboveground Storage Tank, will be closed by taking no further action. As a BMP, the liquid and solid contents of the AST and distribution box will be removed, solidified if necessary, and disposed of at an appropriate facility. The AST, aboveground piping, and distribution box will then be removed and disposed of at an appropriate facility. According to the CAU 543 CADD (NNSA/NSO, 2004), residual material in the Building 15-06 floor drain trenches did not contain COCs above action levels and will be grouted to grade. Appropriate signage will be reestablished around the perimeter of the foundation based on a radiological demarcation survey, as required by the NV/YMP RadCon Manual (DOE/NV, 2004).

CAS 15-04-01, Septic Tank, will be closed by taking no further action. As a BMP, the septic tank contents, the concrete tank structure, and the pipe located on top of the septic tank will be excavated and/or removed and disposed of at an appropriate facility. The excavated area will be backfilled with clean fill. Because there are no COCs associated with this activity, no verification sampling is required before backfilling the excavation.

CAS 15-05-01, Leachfield, will be closed by taking no further action. As a BMP, the contents of the distribution box, the loose pipe located on top of the distribution box, and the distribution box and associated piping between the distribution box and septic tank will be excavated and/or removed and disposed of at an appropriate facility. The excavated area will be backfilled with 
clean fill. No verification samples will be taken from the excavation prior to backfilling due to the fact that no COCs are associated with this activity.

CAS 15-08-01, Liquid Manure Tank, will be closed by taking no further action. As a BMP, the wooden debris in and around the liquid manure tank, the contents of the manure tank, and the tank itself, will be excavated and/or removed and disposed of at an appropriate disposal facility. Because no COCs are associated with this activity, no verification samples will be collected prior to backfilling the excavation.

CAS 15-23-01, Underground Radioactive Material Area, will be closed by taking no further action. As a BMP, the steel grate and miscellaneous debris will be removed and disposed of at an appropriate facility. A radiological demarcation survey will be conducted to determine whether or not the current posting can be downgraded or removed, and appropriate signage will be re-established around the perimeter of the CAS based on the demarcation survey results, as required by the RadCon Manual (DOE/NV, 2004).

CAS 15-23-03, Contaminated Sump, Piping, will be closed in place with administrative controls by backfilling and compacting the sump with clean fill material, grading the sump area to prevent precipitation runon, reestablishing the Underground Radioactive Material Area signs around the perimeter of the sump, and establishing a monitoring program to ensure that the radiological postings are in place and legible.

\subsection{Corrective Action Plan Contents}

This CAP is comprised of the following sections and appendices:

Section $1.0 \quad$ Introduction

Section 2.0 Detailed Statement of Work

Section $3.0 \quad$ Schedule

Section 4.0 Post-Closure Plan

Section $5.0 \quad$ References

Appendix A.1 Engineering Specifications and Drawings

Appendix A.2 Sampling and Analysis Plan

Appendix A.3 Project Organization

Library Distribution List

Appendix A.1 is included in this CAP as required by the approved FFACO CAP outline, but contains no material because engineering specification or drawings are not necessary for site closure. Similarly, Appendix A.2 is included as required but contains no material, because Section 2.4 provides sufficient detail on sample collection.

This report was developed using information and guidance from the following documents:

- Federal Facility Agreement and Consent Order (FFACO, 1996)

- Corrective Action Investigation Plan for Corrective Action Unit 543 (NNSA/NSO, 2004)

- Corrective Action Decision Document for Corrective Action Unit 543 (NNSA/NSO, 2005) 
CAU 543 CAP

Section: Introduction

Revision: 0

Date: September 2006

THIS PAGE INTENTIONALLY LEFT BLANK 


\subsection{DETAILED STATEMENT OF WORK}

\subsection{CORRECTIVE ACTIONS}

Three corrective action alternatives for CAU 543 were identified in the CADD (NNSA/NSO, 2005):

Alternative 1 - No Further Action

Alternative 2 - Clean Closure

Alternative 3 - Closure in Place with Administrative Controls

\subsubsection{Alternative 1 - No Further Action}

Of the three alternatives listed above, the approved corrective action is No Further Action (Alternative 1) for the CASs listed below (NNSA/NSO, 2005).

\subsubsection{CAS 15-01-03, Aboveground Storage Tank}

CAS 15-01-03 consists of a radiologically contaminated 25,000-gal tank located within a pit south of the former location of Building 15-06, the associated piping between the tank and the Building 15-06 foundation, and the exterior holding pens. The tank contains waste from the metabolism and slaughter rooms within Building 15-06 as well as waste from the EPA Farm holding pens.

Though no COCs above action levels were reported during site characterization (NNSA/NSO, 2005), because the AST contains liquids and sediments, the liquid and solid contents of the AST and distribution box will be separated if possible, removed, and disposed of as low-level radioactive waste (LLW) at an appropriate facility. The AST, aboveground piping, and distribution box, will be excavated, removed, and disposed of as LLW. Prior to disposal, foam or other material will be used to fill any remaining void spaces within the AST. Any sediment remaining in the Building 15-06 floor drain trenches will be removed and disposed of as hydrocarbon waste, and the trenches will be filled with concrete. The distribution box excavation will be filled with clean fill, and appropriate signage will be reestablished around the perimeter based on demarcation survey results, as required by the RadCon Manual (DOE/NV, 2004). No verification sampling will be performed prior to the backfilling of the distribution box excavation due to the fact that no COCs are associated with this activity.

\subsubsection{CAS 15-04-01, Septic Tank}

CAS 15-04-01 is located at the former EPA Farm in Area 15 and consists of a 1,000-gal septic tank, piping, and a cleanout southeast of Building 15-06. Four floor drains, four sinks, and one toilet discharged to the septic tank from the Small Animal Laboratory, Biology Laboratory, Utility Room, and restroom within Building 15-06.

No COCs above action levels were detected (NNSA/NSO, 2005). As a BMP, the septic tank contents, the concrete tank structure, and the pipe located on top of the septic tank will be excavated and/or removed, solidified with native fill if necessary, and disposed at an appropriate facility. Specifically, approximately 300 gal of fluid from the influent portion of the septic tank 
will be pumped into a lined basin, solidified with NTS native fill, and disposed of as LLW. Approximately 200 gal will be removed from the effluent portion of the tank, pumped into a lined basin and solidified, and disposed of as hydrocarbon waste along with the loose pipe located atop the tank. The septic tank itself will then be disposed of as LLW, and the excavated area will be backfilled with clean fill. No verification sampling is required prior to backfilling the excavation due to the fact that no COCs are associated with this activity.

\subsubsection{CAS 15-05-01, Leachfield}

CAS 15-05-01 is located at the former EPA Farm in Area 15 and consists of a leachfield and distribution box southeast of the Building 06-15 foundation. No COCs are present at this site above action levels (NNSA/NSO, 2005). As a BMP, the contents of the distribution box, the loose pipe located on top of the distribution box, and the distribution box and associated piping between the distribution box and the CAS 15-04-01 septic tank will be excavated and/or removed, solidified with native fill if necessary, and disposed of as LLW at an appropriate facility. The excavated area will then be backfilled with clean fill. No verification sampling is required prior to backfilling the excavation due to the fact that no COCs are associated with this activity.

\subsubsection{CAS 15-08-01, Liquid Manure Tank}

CAS 15-08-01 is located at the former EPA Farm in Area 15 and consists of a liquid manure tank, associated piping, and a concrete pad and drain northwest of the Building 15-06 foundation, which were used for the disposal of excess milk from the dairy cows, and wastes from the autopsy laboratory, milking room, and metabolism room. No COCs are present at this site above action levels (NNSA/NSO, 2005). As a BMP, the wooden debris in and around the liquid manure tank will be disposed of as hydrocarbon waste. The contents of the manure tank and the tank itself will be excavated and/or removed and disposed of as LLW at an appropriate disposal facility. No verification sampling is required prior to backfilling any excavation at this CAS due to the fact that no COCs are associated with this activity.

\subsubsection{CAS 15-23-01, Underground Radioactive Material Area}

CAS 15-23-01 is located at the former EPA Farm in Area 15 and consists of an area of soil surrounding and underlying a PSP (e.g., grate) measuring approximately 19 by $22 \mathrm{ft}$. No COCs are present above action levels (NNSA/NSO, 2005). As a BMP, the steel grate and miscellaneous debris will be removed and disposed of as sanitary waste at an appropriate facility. A demarcation survey will be conducted to determine whether or not the "Underground Radiological Material Area” posting can be downgraded or removed, and appropriate signage will be reestablished around the perimeter of the CAS based on the demarcation survey results, as required by the RadCon Manual (DOE/NV, 2004).

\subsubsection{Alternative 3 - Closure in Place with Administrative Controls}

Of the three alternatives listed above, the approved corrective action is Closure in Place with Administrative Controls (Alternative 3) for the CASs listed below (NNSA/NSO, 2005). 


\subsubsection{CAS 06-07-01, Decon Pad}

CAS 06-07-01 is located at the Decontamination Facility in Area 6. The CAS consists of the effluent collection and distribution systems for Buildings 6-605, 6-606, and 6-607, which include two 1,000-gal septic tanks, two ground-level sumps and associated piping, the concrete foundation of Building 6-605, floor drains, drain trenches, and cleanouts.

PCBs are present above action levels in the soil at 19 locations around the Decontamination Facility (Building 6-605) foundation and are considered COCs. A land UR will be implemented for the area extending 10 lateral ft from the Building 6-605 foundation. The outside perimeter of the area will be fenced and UR warning signs posted according to the FFACO UR posting guidance (FFACO, 2003).

As a BMP, the contents of the Building 6-605 septic tank will be pumped into a lined basin, solidified with native fill, and disposed of as hydrocarbon waste. The contents of the Building 6607 septic tank, Sumps 1 and 2, and the diversion box will be pumped into a lined basin, solidified with native fill, and disposed of as LLW. The septic tanks, sumps, and associated piping will then be removed and/or excavated and disposed of at the appropriate disposal facility. Pending verification sample results, all excavations will be backfilled with NTS clean native fill. All floor drains and trenches will be filled with concrete and all open holes, diversion boxes, and cleanouts will be grouted to grade. Any remaining debris will be assumed LLW and disposed of accordingly. All containers, drums, and associated waste within the storage yard will be sampled, if necessary, and disposed of at an appropriate facility.

\subsubsection{CAS 15-23-03, Contaminated Sump, Piping}

CAS 15-23-03 is located at the former EPA Farm in Area 15 and consists of a sump and associated piping between the sump and the CAS 15-01-03 distribution box. The sump, which was in operation from 1972 to 1981, was used primarily for the collection of liquid waste from the Building 15-06 laboratory. PCB and plutonium-238 concentrations above action levels are present in the soil at the sump floor, and will be closed in place with administrative controls by backfilling and compacting the sump with clean fill material, grading the sump area to prevent precipitation runon, reestablishing the Underground Radioactive Material Area signs around the perimeter of the sump, implementing a UR, and establishing a monitoring program to ensure that the radiological and UR postings are in place and legible. 
Figure 2. CAS 06-07-01, DECON PAD 
FIGURE 3. CASs 15-01-03, 15-04-01, 15-05-01, 15-08-01, 15-23-01, AND 15-23-03 LOCATED AT THE AREA 15 EPA FARM 


\subsection{CONSTRuction Quality Assurance / Quality ConTrol}

Construction activities are limited to excavation, backfilling, removal of liquids from the sumps and septic tanks, and solidification of removed liquids. No engineered structures will be constructed as part of site closure. Therefore, a construction quality assurance/quality control (QA/QC) plan will not be required.

\subsubsection{Construction Field Sample Collection Activities}

Construction field samples are not necessary for the closure of any CASs listed in this CAP, although samples will be collected for the purpose of waste stream characterization. Field sample collection activities are addressed in Section 2.4.

\subsubsection{Construction Laboratory/Analytical Data Quality Indicators}

CAU 543 closure activities are limited to debris removal, site fencing and posting, non-structural excavation and backfilling, and draining of fluid from septic tanks, distribution boxes, and piping. Therefore, a construction QA/QC plan is not required and Construction data quality indicators (DQIs) are not applicable. To ensure that backfill material remains consistent, all fill will be taken from an approved NTS borrow source.

\subsection{WASTE MANAGEMENT}

All waste will be managed and disposed of in accordance with applicable federal and state regulations, DOE orders, U.S. Department of Transportation, and National Security Technologies, LLC (NSTec) waste management procedures. CAU 543 closure activities are expected to generate sanitary waste/construction debris, hydrocarbon waste, and LLW. Waste generated during closure activities will be properly managed and shipped to onsite or offsite disposal facilities. Confirmation of waste disposal or transfer to NSTec Waste Generator Services (WGS) for management and disposal shall be included in the CAU 543 Closure Report (CR).

\subsubsection{Waste Minimization}

All work activities that generate waste will follow the NSTec Waste Minimization and Pollution Prevention Program. Special care will be given to properly characterize and segregate the waste streams to avoid the generation of additional waste.

\subsubsection{Waste Types}

\section{Sanitary Waste}

Sanitary waste (e.g., non-impacted personal protective equipment [PPE] and general trash) and construction debris (e.g., wood, concrete, block, metal, plastic) will be generated during closure activities for CAU 543. All sanitary waste removed from sites will be screened for free release (U.S. Department of Energy, Nevada Operations Office [DOE/NV], 2004) and disposal. It will be disposed of in an onsite landfill. 


\section{Hydrocarbon Waste}

All hydrocarbon waste will be analyzed for gamma-emitting radionuclides by either the In-Situ Object Counting System or laboratory analysis, in order to satisfy the landfill disposal restrictions. Upon receipt of the analytical results, the waste will be properly characterized and disposed. Any waste meeting the land disposal restrictions as specified in the landfill permit will be disposed in the Area 6 Hydrocarbon Landfill. Hydrocarbon waste not meeting the landfill disposal restrictions for radionuclides will be stored in a waste accumulation area and disposed of as LLW.

\section{Low-Level Waste}

Closure activities will include removal of contaminated solidified fluids, tanks, piping, boxes, and debris impacted with varying combinations of plutonium-238, plutonium-239, americium-241, cobalt-60, cesium-137, uranium-235, uranium-238, and strontium-90. All LLW will be characterized by laboratory analysis, and a profile for disposal will be prepared. Analyses of the waste will include PCBs, transuranics, and isotopic plutonium. All LLW shall be managed and disposed in accordance with Organization Procedure (OP) OP-2151.304, "Radioactive Waste Tracking, Handling, and Management at the NTS" (Bechtel Nevada [BN], 2004a), and all applicable federal and state regulations. All LLW will be packaged in the presence of a Waste Certification Official and WGS personnel according to OP-2151.304 (BN, 2004a). All LLW will be stored in a Radioactive Materials Area until a waste disposal profile is prepared and approved. The LLW will then be disposed appropriately.

\section{PCBs/Hazardous Waste}

It is not anticipated that hazardous waste will be generated during CAU 543 closure activities. Should any waste be discovered through characterization sampling of drums (CAS 06-07-01) or other waste, the waste will be characterized by WGS, and a waste profile will be prepared. The waste will be managed and disposed according to all applicable NSTec procedures and state and federal regulations. Upon generation, the waste shall be containerized and stored in a satellite accumulation area or a 90-Day Hazardous Waste Accumulation Area, depending on the amount of waste generated. After an approved waste profile is generated, the waste will be disposed of at an appropriate permitted treatment, storage, and disposal (TSD) facility.

\section{Personal Protective Equipment}

All PPE that becomes contaminated during closure activities shall be disposed of with the appropriate corresponding waste stream. All wastes generated during closure activities will be properly disposed of in onsite landfills or at a permitted offsite TSD facility.

\section{Decontamination Waste}

Equipment that becomes contaminated during closure activities will be decontaminated onsite. Dry decontamination will be the preferred method. For larger pieces of equipment that cannot be effectively decontaminated using dry decontamination techniques, wet decontamination techniques shall be used over a drum or waste pile. For larger equipment, a decontamination pad consisting of a lined bermed area will be used. The equipment will be driven onto the pad and decontaminated using pressurized water. Smaller equipment and/or tools may be 
decontaminated with soap and water. All decontamination rinseate will be managed appropriately in accordance with all applicable regulations, and once characterized, properly disposed.

\subsection{CONFIRMATION OF CORRECTIVE ACTIONS}

Accurate and defensible analytical data will be collected to characterize waste and to verify that the closure objectives outlined in this CAP have been met. The completion of BMP activities will be verified via physical observations, visual inspections, image documentation, and waste disposition documentation.

\subsubsection{Sample Collection Methods}

Due to the fact that no specific COCs are present at the CAU 543 CASs where excavations are being performed as a BMP, the collection of verification samples is not required during closure of CAU 543. Waste characterization samples may be collected, and all samples will be collected by qualified NSTec Environmental Restoration personnel. Surface soil samples will be collected using scoop and trowel or hand auger. Subsurface soil samples will be collected using drilling or pushing methods (e.g., hollow-stem auger, Geoprobe, or other applicable methods). Samples collected for required analysis are discussed in Section 2.1.3. All sampling activities will follow Organization Instruction (OI) OI-2152.108, “Soil Sampling” (BN, 2000a).

Sample traceability is established and maintained by completing a chain of custody form, as detailed in "Sample Chain of Custody," OI-2152.100 (BN, 2002). Sample collection date, time, and other pertinent information will be logged on a "Service Request and Chain of Custody Record," and placed in a bound project field notebook.

All samples will be collected in clean containers, labeled appropriately, sealed with a tamper-proof seal, bagged, placed on ice in a cooler, and transported to the NSTec Environmental Technical Services group under a sample chain of custody form. The NSTec Environmental Technical Services group will be responsible for sample management and shipment of the samples to an approved offsite laboratory for analysis. Samples will be analyzed by EPA-approved analytical methods at EPA-approved laboratories (EPA, 1996). Sample analysis will include laboratory analysis of QA/QC samples and will follow stringent QA/QC procedures (EPA, 1996). Sample analysis for radioisotopes will be performed in accordance with Environmental Measurements Laboratory Procedures Manual (DOE, 1997).

One set of QA/QC samples will be collected for every 20 environmental samples. QA/QC samples will include blind duplicates and matrix spike/matrix spike duplicates. The blind duplicate will be labeled with a unique sample number.

\subsubsection{Laboratory/Analytical Data Quality Objectives}

Data quality objectives (DQOs) are qualitative and quantitative statements that specify the quality of the data required to support closure of a site. The DQOs for CAU 543 site investigations were defined in the CAIP (NNSA/NSO, 2004) using the seven-step DQO process 
developed by EPA (EPA, 2000). The conceptual site models for the CAU 543 CASs were defined in the CAIP (NNSA/NSO, 2004), and these models were reconciled with the results of the site investigation in the CADD (NNSA/NSO, 2005). (See Appendix A of the CADD.)

Sample analytical results may be generated during closure activities for each CAS that will involve excavations, which may require the collection and analysis of verification soil samples. All laboratory data generated during closure activities will be reviewed by project personnel, to ensure the data are usable and complete according to the CAU 543 DQOs. In addition, as specified in the Industrial Sites Quality Assurance Project Plan (NNSA/NV, 2002), a minimum of 100 percent of the final data packages for verification samples will be evaluated at the Tier I and Tier II levels using the applicable OIs. These include OI-2151.303 (BN, 2004b) for validating radiological data, and OI-2154.459 (BN, 2003) for validating inorganic chemical data. OI-2154.459 is based on EPA Functional Guidelines (EPA, 2002). Any data determined not to be valid will be identified in the CR. More details on the proposed number and location of the verification samples are given in Section 2.1.3 of this CAP.

DQIs are qualitative and quantitative statements that specify the data requirements of a project. The DQIs include precision, accuracy completeness, representativeness, comparability, and sensitivity. These DQIs are discussed below.

\section{Precision}

Precision is a measure of agreement among a replicate set of measurement of the same property under similar conditions. This agreement is expressed as the relative percent difference (RPD) between duplicate measurements (EPA, 1996). Precision applies to parameters sampled and analyzed in duplicate.

One duplicate sample will be collected per set of 20 or fewer verification samples. All duplicate samples will be collected from the same medium and analyzed for the same set of analytes as verification samples. The precision of the analytical results will be assessed by calculating the RPD for a verification sample and its duplicate sample results. An RPD of less than or equal to 30 percent indicates acceptable precision (NNSA/NV, 2002).

\section{Accuracy/Bias}

Accuracy is a measure of the closeness of an individual measurement or the average of a number of measurements to the true value. Accuracy includes a combination of random error (precision) and systematic error (bias) components that result from sampling and analytical operations. This closeness is represented as percent recovery (\%R) (EPA, 1996). Accuracy will be assessed by examining the \%R of laboratory control and spiked samples. A \%R within the range of 70-130 percent indicates satisfactory analytical accuracy (NNSA/NV, 2002).

\section{Representativeness}

Representativeness is a qualitative evaluation of measurement system performance. It is the degree to which sample data accurately and precisely represent a characteristic of a population, parameter variations at a sampling point, or an environmental condition (EPA, 1996). 
Representativeness will be attained by ensuring that the sample locations, analytical parameters, analytical methods, sampling protocols, and sample handling all meet the project-specific objectives.

\section{Comparability}

Comparability is a qualitative measure that expresses the confidence that one data set can be compared to another. It will be achieved by using standardized field sampling procedures and same analytical methods for sample analysis. Sample results will be reported in standard units to allow for comparison of the data.

\section{Completeness}

Completeness is a quantitative measure of data quality expressed as the percentage of valid data obtained that satisfies the project-specific requirements. Because a limited number of samples will be collected for both waste characterization and verification of closure, 100 percent of the data collected needs to be of acceptable quality to maintain acceptable QA/QC standards.

\section{Sensitivity}

Sensitivity is the capability of a method or instrument to discriminate between measurement responses representing different levels of a variable of interest. This indicator is determined from the value of the standard deviation at the concentration level of interest. It represents the minimum difference of concentration that can be distinguished between two samples with a high degree of confidence. Sensitivity must be sufficient to detect contaminants at or below decision levels. Sensitivity will be achieved by analyzing all samples using appropriate EPA-approved analytical laboratories, methods, and instruments.

\subsection{Permits}

Prior to beginning field closure activities, planning documents and permits will be prepared. These documents will include a Field Management Plan, National Environmental Policy Act (NEPA) Checklist, NNSA/NSO Real Estate/Operations Permit (REOP), Radiological Work Permits (RWP), excavation permits, and blind penetration permits.

\section{National Environmental Policy Act Checklist}

A NEPA Checklist will be completed prior to all excavation activities at the site. Excavation activities will follow all applicable federal, state, and local laws, regulations, and permits regarding protection of the environment.

\section{NNSA/NSO Real Estate/Operations Permit}

A REOP will be obtained prior to beginning closure activities. The permit will establish the NNSA/NSO as the prime authority possessing control of the site. 


\section{Radiological Work Permit}

RWPs will be required for work at any radiologically-impacted site when radiological conditions require, as determined by NSTec Health Physics. RWPs will inform workers of the specific PPE necessary to protect them while performing their tasks and identify site-specific controls. The workers will be required to sign the permits and acknowledge their understanding of the requirements before entry into any contamination area, if present. The RWPs will be maintained by Radiological Control Technicians at the entrance to the contamination area. All site workers will be required to be Radiation Worker II-trained to perform any work within a radiologically controlled area.

\section{Excavation Permits and Blind Penetration Permits}

An excavation permit will be obtained prior to beginning any excavation activities. These permits require that a utility clearance also be performed. A copy of the permit will be filed on the site throughout the duration of the project. 
CAU 543 CAP

Section: Detailed SOW

Revision: 0

Date: September 2006

THIS PAGE INTENTIONALLY LEFT BLANK 


\subsection{SCHEDULE}

All preparation and field activities are scheduled for completion in Fiscal Year 2007. The FFACO deadline for delivery of the CR to the Nevada Division of Environmental Protection is January 31, 2008. Sufficient flexibility has been incorporated into the field schedule to allow for minor difficulties (e.g., weather, equipment failure). The NNSA/NSO shall notify the Nevada Division of Environmental Protection of any condition or event that may impact the project schedule. 
CAU 543 CAP

Section: Schedule

Revision: 0

Date: September 2006

THIS PAGE INTENTIONALLY LEFT BLANK 


\subsection{POST-CLOSURE PLAN}

Corrective Action Alternative 3, Closure in Place with Administrative Controls, requires post-closure site inspections. The Administrative Controls will include implementing a UR at CAS 06-07-01 and CAS 15-23-03 to prohibit any unauthorized intrusive activities.

\subsection{INSPECTIONS}

Annual inspections will be completed at CAS 06-07-01 and CAS 15-23-03. Inspections consist of annual (yearly) visual inspections of the postings to verify that the postings are in place and readable and that the URs are maintained. Any identified maintenance and repair requirements will be reported to the Nevada Division of Environmental Protection (NDEP) and maintenance scheduled within 90 working-days of discovery.

Results of all inspections in a given year will be included in the annual NTS Industrial Sites Post-Closure letter report. The annual letter report will include the following information:

- Discussion of observations and inspections

- Copies of the site inspection checklists

- Any maintenance records

A copy of each annual letter report will be submitted to the NDEP.

\subsection{MONITORING}

Because no sampling or collection of data will be performed after closure of the CAU, no post-closure monitoring is required for these CASs. Annual visual inspection will be performed for the CASs identified in Section 4.1, "Inspections."

\subsection{MAINTENANCE AND REPAIR}

If any maintenance and repair requirements are identified during the annual inspection of CAS 06-07-01 and CAS 15-23-03, the NDEP will be notified, funding will be requested, and the repairs scheduled. Any repair or maintenance performed at this site shall be documented in writing at the time of the repair and included in the annual letter report. 
CAU 543 CAP

Section: Post-Closure Plan

Revision: 0

Date: September 2006

THIS PAGE INTENTIONALLY LEFT BLANK 


\subsection{REFERENCES}

BN, see Bechtel Nevada.

Bechtel Nevada. 2000a. Organization Instruction OI-2152.108. "Soil Sampling.” Las Vegas, NV.

Bechtel Nevada. 2000b. Organization Instruction OI-2152.100. “Sample Chain of Custody.” Las Vegas, NV.

Bechtel Nevada. 2003. Organization Instruction OI-2154.459. “Inorganic Data Verification and Validation.” Las Vegas, NV.

Bechtel Nevada. 2004a. Organization Procedure OP-2151.304, Revision 5. "Radiological Waste Tracking, Handling, and Management at the NTS.” Las Vegas, NV.

Bechtel Nevada. 2004b. Organization Instruction OI-2151.303. “Validation of Radiological and Chemical Laboratory Data.” Las Vegas, NV.

DOE, see U.S. Department of Energy.

DOE/NV, see U.S. Department of Energy Nevada Operations Office.

EPA, see U.S. Environmental Protection Agency.

FFACO, see Federal Facility Agreement and Consent Order.

Federal Facility Agreement and Consent Order. 1996 (as amended). Agreed to by the State of Nevada, the U.S. Department of Energy, and the U.S. Department of Defense.

Federal Facility Agreement and Consent Order. 2003. FFACO Use Restriction Post Guidance for NNSA/NSO and Associated Contractors. Las Vegas, NV.

NDEP, see Nevada Division of Environmental Protection.

NNSA/NSO, see U.S. Department of Energy, National Nuclear Security Administration Nevada Site Office.

NNSA/NV, see U.S. Department of Energy, National Nuclear Security Administration Nevada Operations Office. 


\section{REFERENCES (continued)}

U.S. Department of Energy. 1997. Environmental Measurements Laboratory Procedures Manual, HASL-300, $28^{\text {th }}$ Ed., Vol. 1. New York, NY.

U.S. Department of Energy, National Nuclear Security Administration Nevada Operations Office. 2002. Industrial Sites Quality Assurance Project Plan, Nevada Test Site, Nevada, Rev. 3, DOE/NV--372. Las Vegas, NV.

U.S. Department of Energy, National Nuclear Security Administration Nevada Site Office. 2004. Corrective Action Investigation Plan for Corrective Action Unit 543: Liquid Disposal Units, Nevada Test Site, Nevada, DOE/NV--968. Las Vegas, NV.

U.S. Department of Energy, National Nuclear Security Administration Nevada Site Office. 2005. Corrective Action Decision Document for Corrective Action Unit 543: Liquid Disposal Units, Nevada Test Site, Nevada, DOE/NV--1082. Las Vegas, NV.

U.S. Department of Energy, Nevada Operations Office. 2004. NV/YMP Radiological Control Manual, DOE/NV/11718-079, Rev. 5. Las Vegas, NV.

U.S. Environmental Protection Agency. 1996. Test Methods for Evaluating Solid Waste Physical/Chemical Methods, SW-846, Third Edition. Washington, D.C.

U.S. Environmental Protection Agency. 2000. Guidance for Data Quality Assessment: Practical Methods for Data Analysis, EPA QA/G-9, EPA/600/R-96/055. Washington, D.C.

U.S. Environmental Protection Agency. 2002. Contract Laboratory Program National Functional Guidelines for Inorganic Data Review, EPA/540/R-94/013. Washington, D.C. 


\section{APPENDIX A.1}

\section{ENGINEERING SPECIFICATIONS AND DRAWINGS}

NOTE: Engineering specifications and drawings are not required for closure of CAU 543. This Appendix is included here as required by the approved Federal Facility Agreement and Consent Order outline for a Corrective Action Plan. 
CAU 543 CAP

Section: Appendix A.1

Revision: 0

Date: September 2006

THIS PAGE INTENTIONALLY LEFT BLANK

A.1-2 


\section{APPENDIX A.2}

\section{SAMPLING AND ANALYSIS PLAN}

NOTE: Sufficient details on the type, number, and location of verification samples to be collected to verify site closure activities has been provided in Section 2.4, "Confirmation of Corrective Actions.” This Appendix is included here as required by the approved Federal Facility Agreement and Consent Order outline for a Corrective Action Plan. 
CAU 543 CAP

Section: Appendix A.2

Revision: 0

Date: September 2006

THIS PAGE INTENTIONALLY LEFT BLANK

A.2-2 


\section{APPENDIX A.3}

\section{PROJECT ORGANIZATION}


CAU 543 CAP

Section: Appendix A.3

Revision: 0

Date: September 2006

THIS PAGE INTENTIONALLY LEFT BLANK

A.3-2 


\section{PROJECT ORGANIZATION}

The U.S. Department of Energy, National Nuclear Security Administration Nevada Site Office (NNSA/NSO) Federal Sub-Project Director is Kevin Cabble, and his telephone number is (702) 295-5000

The identification of the project Health and Safety Officer and the Quality Assurance Officer can be found in both the Field Management Plan and the Site-Specific Health and Safety Plan. However, personnel are subject to change, and it is suggested that the appropriate NNSA/NSO Project Manager be contacted for further information. The Task Manager will be identified in the Federal Facility Agreement and Consent Order Monthly Activity Report prior to the start of field activities. 
CAU 543 CAP

Section: Appendix A.3

Revision: 0

Date: September 2006

THIS PAGE INTENTIONALLY LEFT BLANK 
CAU 543 CAP

Section: Library Distribution

Revision: 0

Date: September 2006

\section{LIBRARY DISTRIBUTION LIST}


CAU 543 CAP

Section: Library Distribution

Revision: 0

Date: September 2006

THIS PAGE INTENTIONALLY LEFT BLANK 


\section{LIBRARY DISTRIBUTION LIST}

U.S. Department of Energy

National Nuclear Security Administration

Nevada Site Office

Technical Library

P.O. Box 98518, M/S 505

Las Vegas, NV 89193-8518

U.S. Department of Energy

Office of Scientific and Technical Information

P.O. Box 62

Oak Ridge, TN 37831-0062

Southern Nevada Public Reading Facility

c/o Nuclear Testing Archive

P.O. Box 98521, M/S 400

Las Vegas, NV 89193-8521

Manager, Northern Nevada FFACO

Public Reading Facility

c/o Nevada State Library \& Archives

Carson City, NV 89701-4285
1 (Uncontrolled)

1 (Uncontrolled, electronic copy)

2 (Uncontrolled, electronic copies)

1 (Uncontrolled, electronic copy) 
CAU 543 CAP

Section: Library Distribution

Revision: 0

Date: September 2006

THIS PAGE IS INTENTIONALLY LEFT BLANK 